\title{
The Dynamic Absence of Jesus in Hebrews
}

\author{
Markus Bockmuehl, University of Oxford \\ markus.bockmuehl@keble.ox.ac.uk
}

\begin{abstract}
How does Hebrews negotiate the whereabouts of the risen Jesus, on the dialectical spectrum between physical and indeed metaphysical absence on the one hand, and affirmations of a continuing or intermittent presence on the other? More than perhaps any other NT writing, Hebrews concentrates on Jesus's distance from the world of earthly Christian life and discipleship. And yet the author's 'word of encouragement' (13.22) evidently serves his recipients' situation more urgently through its emphasis on the Son's heavenly high priesthood rather than on his immediate presence. The presence of Jesus is here most clearly articulated in relation to his incarnation in the past: unlike elsewhere in the New Testament, no obvious attempt is made to sublimate or compensate for the absence of Jesus by sacramental, mystical or pneumatological means. Nevertheless, even the pastness of the incarnation remains a powerful and abiding ingredient both in Christ's ongoing priestly work and in the expectation of his coming. As a result, Jesus's seeming remoteness in Hebrews remains in important respects compatible with his continuing accessibility and closeness to pilgrim believers.
\end{abstract}

Where is Jesus now? This question, at once foundational to faith and often neglected in theology, tends to attract a remarkable range of proposed answers - not infrequently in terms of experiential sublimation of one kind or another. At the heart of Christian faith since antiquity is a creedal conviction that Jesus of Nazareth rose from the dead after his crucifixion and was exalted to heaven. But this belief also raises a fundamental puzzle about how this Jesus continues to relate to present Christian faith and experience. Affirming him to be alive and exalted to a world beyond this one, did the apostolic writers therefore assume him to be present or absent to the believer on earth? To these authors, is the post-resurrection Jesus here or somewhere else, at a spatial and perhaps temporal remove from their own situation?

At one level this question is so basic that it has impressed itself on all forms of Christian experience and theology ever since antiquity. And it has evoked a seemingly interminable variety of sometimes highly specified answers to the present day. 
Page $\mathbf{2}$ of $\mathbf{2 1}$

Contemporary Christians of a traditional Catholic mindset might reply that Jesus is present most concretely in the Eucharist and in the Church; Lutherans, in Word and Sacrament; many other Protestants, in the reading or proclamation of Scripture; charismatics, in the experience of the Spirit; and so forth. Certain evangelicals may continue to appeal to the experience of the heart to yield a Jesus who, in the words of a dated revival hymn, 'walks with me and talks with me'. ${ }^{1}$ Within this range of Christian expression, some incline to visionary experience of Jesus or of Mary, others to Jesus' presence in the imaginative discipline of the Ignatian exercises; yet others identify him in their response to imperatives of charity, community-building or social justice.

What does seem clear from all this is that the temporarily absent Jesus is sublimated to popular Christian experience in remarkably varying ways, which may themselves be a function of theological, cultural and indeed temperamental or psychological diversity.

At the same time, both the Creeds and much of the Christian dogmatic tradition are either negative or silent on Jesus's personal whereabouts anywhere other than 'seated at the right hand of the Father', from where 'he shall come to judge the living and the dead'. That appears to leave no room for dialectic, and gives little encouragement to any pietistic or mystical assurance of the sort that 'He lives within my heart' ${ }^{2}$ Academic theology, however, is not a great deal more eloquent on the subject. While official church documents like those of Vatican II occasionally attempt a more formal explanation, in New Testament studies the question of what its authors thought about the continued personal presence or absence of Jesus 'qua Jesus' has rarely featured at the forefront of inquiry. In fact, among some influential twentieth-century interpreters it was quite explicitly deemed illegitimate. ${ }^{3}$ Contemporary reference works in theology or biblical studies rarely foreground the subject.

\footnotetext{
${ }^{1}$ In fact it is interesting that C. Austin Miles (1868-1946), the author of the hymn 'In the Garden' which became a mainstay of Billy Sunday (1862-1935) crusades, claimed that he wrote it in March 1912 after seeing a striking vision of Mary Magdalene visiting the empty tomb. See also n. 4 below.

${ }^{2}$ Alfred H. Ackley (1887-1960), 'He Lives' (first published in 1933): 'He lives! He lives! Christ Jesus lives today! He walks with me and he talks with me along life's narrow way. He lives, he lives, salvation to impart! You ask me how I know he lives? He lives within my heart.'

${ }^{3}$ Explicit refusal to engage the dimension of Jesus as person or personality was one of the hallmarks of Rudolf Bultmann's project. Jesus was for him knowable not as a personal presence but exclusively through the Word, the Kerygma about Christ, which calls forth the hearer's existential response. See e.g. Rudolf Bultmann, Jesus (Tübingen: Mohr (Siebeck), 1926), 180-82.
} 
Our question is undoubtedly complicated by its methodological elusiveness. There are many possible ways to try and contextualize it in either ancient cultural or modern analytical settings. So, for example, there has been extensive work on Jewish, early Christian and Greco-Roman mysticism. ${ }^{4}$ Others have studied the role of interiority and cognitivity in religion, as well as ascetical, shamanistic and neurobiological aspects of ecstatic experience, especially in relation to the Apostle Paul. ${ }^{5}$ Indeed a series of recent studies have called for a fuller discussion of the role of religious experience as a neglected factor in the formation of Christian belief and theology more broadly. ${ }^{6}$

These aspects of our question are of undoubted importance, though perhaps none quite manage to escape a whiff of anachronism. In earlier scholarship, generic and comparative study of religion tended to focus on expressions of divine presence either in terms of the numinous (R. Otto), of social ritual as expressing the power of society (E. Durkheim), or in relation to providential or animistic conceptions of the sort associated in antiquity with the god Pan or with numerous popular local shrines and deities.

\footnotetext{
${ }^{4}$ E.g. Bernhard Heininger, Paulus Als Visionär: Eine Religionsgeschichtliche Studie (Herders Biblische Studien; Freiburg/New York: Herder, 1996); 'Paulus Und Philo Als Mystiker? 2 Kor 12,2-4 Und Spec Leg 3,1-6 Im Vergleich' in Philo Und Das Neue Testament: Wechselseitige Wahrnehmungen : I. Internationales Symposium Zum Corpus Judaeo-Hellenisticum, 1.-4. Mai 2003, Eisenach/Jena, ed. Roland Deines and Karl-Wilhelm Niebuhr (Wissenschaftliche Untersuchungen Zum Neuen Testament; Tuibingen: Mohr Siebeck, 2004): 189-204; Christopher Rowland, The Open Heaven: A Study of Apocalyptic in Judaism and Early Christianity (London: SPCK, 1982); Alan F. Segal, Two Powers in Heaven: Early Rabbinic Reports About Christianity and Gnosticism (Sjla 25; Leiden: Brill, 1977); 'Heavenly Ascent in Hellenistic Judaism, Early Christianity and Their Environment', Aufstieg und Niedergang der römischen Welt 2.23.2 (1980): 1333-94; Paul the Convert: The Apostolate and Apostasy of Saul the Pharisee (New Haven: Yale University Press, 1990).

5 See e.g. Michael Reichardt, Psychologische Erklärung Der Paulinischen Damaskusvision? Ein Beitrag Zum Interdisziplinären Gespräch Zwischen Exegese Und Psychologie Seit Dem 18. Jahrhundert (Stuttgart: Katholisches Bibelwerk, 1999); Terrance Callan, Psychological Perspectives on the Life of Paul: An Application of the Methodology of Gerd Theissen (Studies in the Bible and Early Christianity; Lewiston: Mellen, 1990); Gerd Theissen, 'The New Perspective on Paul and Its Limits: Some Psychological Considerations', Princeton Seminary Bulletin 28 (2007): 64-85 for psychological approaches; also John Ashton, The Religion of Paul the Apostle (New Haven/London: Yale University Press, 2000) on shamanism, Calvin J. Roetzel, Paul: The Man and the Myth (Edinburgh: T\&T Clark, 1998) on asceticism, and Colleen Shantz, Paul in Ecstasy: The Neurobiology of the Apostle's Life and Thought (Cambridge/New York: Cambridge University Press, 2009) on neurobiology.

${ }^{6}$ See e.g. Joanna R. Collicutt, 'Bringing the Academic Discipline of Psychology to Bear on the Study of the Bible', The Journal of Theological Studies ns 63 (2012): 1-48, 20-22 and passim and note e.g. the SBL series Experientia: Frances Flannery et al., ed., Experientia (2 vols vols.; Atlanta: Society of Biblical Literature, 200812); Luke Timothy Johnson, Religious Experience in Earliest Christianity: A Missing Dimension in New Testament Studies (Minneapolis: Fortress Press, 1998); Larry W. Hurtado, 'Religious Experience and Religious Innovation in the New Testament', The Journal of Religion 80 (2000): 183-205; 'Revelatory Experiences and Religious Innovation in Earliest Christianity', The Expository Times 125 (2014): 469-86,
} 
We could go on. I do not doubt that many of these modes of characterizing divine presence are relevant to a description of early Christian realities: quite likely they are. Here, however, I would like here to probe the more focused and in a sense 'dogmatic' question about how Hebrews negotiates specifically the whereabouts of Jesus of Nazareth after his earthly lifetime: how does this author handle the dialectic between his physical and indeed metaphysical absence on the one hand, and affirmations of his continuing or intermittent presence on the other? To this end I am less concerned with a comparative phenomenology of ancient religious experience than with stated affirmations about the presence or the absence of Jesus - the convictions that shaped and were in turn shaped by this author's community.

All of the New Testament authors reflect in their different ways on that complex and dialectical relationship between the present and the absent Jesus. He is alive and in his identity continuous with Jesus of Nazareth, but not now visible and tangible. He is near and present to his followers in some significant way, but also now absent and distant in heaven until his future return in glory. And even in his absence he is mediated at present to believers in one or more quite different ways - by the Spirit of God, in the church and its worship, eucharistic and otherwise; in the apostolic word and authority, including disciplinary judgment; and at least for some believers some of the time, in mystical experiences including visions. Some of these mediations seem primarily to sublimate or substitute for the absence of Jesus; but in other cases one encounters clear affirmations of his personal presence qua Jesus.

In other words, while all the New Testament writers to some degree modulate this dialectic of presence and absence, they do so on quite a wide spectrum. At one end of this spectrum is a text like the Gospel of Matthew, where Jesus' very name is Emmanuel, 'God with Us'; where even after the resurrection he remains permanently present with the disciples until the end of the age and in their midst whenever they gather in his name - and where, in striking contrast to the three other gospels, he never goes away. ${ }^{7}$

As I hope to show in this essay, the Letter to the Hebrews lies near the opposite end of that spectrum. At least at first sight, that text strongly foregrounds the absence of Jesus

${ }^{7}$ Matt 1.23/28.20 (inclusio); 18.20. 
over his presence, a unique emphasis that makes it like Matthew an important pole of reference for this discussion. Written perhaps not long after the 70, perhaps for Jewish believers in Jesus seeking to understand their faith in the wake of the Temple's destruction, it seeks to encourage in its audience a renewed confidence in the redemptive all-sufficiency of Christ's sacrifice and eternal intercession. ${ }^{8}$

\section{The Letter to the Hebrews}

Readers of Hebrews encounter from the outset a striking and distinctive view of Jesus, forthright in its claims about both his divinity and his humanity and uniting in the same text some of the New Testament's 'highest' and 'lowest' Christological claims. The register of Hebrews extends at one end to the Son who is higher than the angels, 'the exact imprint of God's very being', creating and sustaining the worlds by the power of his word (1.2-3). At the same time Hebrews reaches all the way to the incarnate Jesus who suffered and was tested (1.11-16), learning obedience through that suffering in the days of his flesh and tearfully crying out in prayer to be saved from death (5.7-8). Jesus thus became the pioneer and leader of his followers in entering the heavenly sanctuary as the eternal high priest and bringing many to salvation $(2.10 ; 4.14 ; 6.16 ; 9.12 ; 12.2)$.

But how does the author envisage the presence or absence of that once-incarnate and exalted figure of Jesus to the believer here and now? In Hebrews, the dialectical answer given by most other New Testament authors appears in some respects in a more striking polarization that invites further explanation.

\section{Past Presence: Jesus Then and Here}

Implicit in the narrative Christological movement throughout Hebrews is a remarkably sharp temporal distinction between then and now: the past is the time in which God

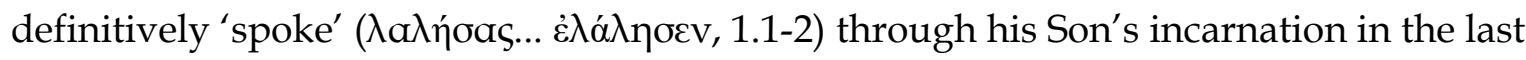

\footnotetext{
${ }^{8}$ We are still far from a consensus on the date, authorship and audience of Hebrews none of which materially alters the argument of this essay. While a broadly Jewish Christian setting after 70 has long been entertained, it has recently been strengthened by attempts (like that of Gabriella Gelardini, 'Hebrews, an Ancient Synagogue Homily for Tisha Be-Av: Its Function, Its Basis, Its Theological Interpretation' in Hebrews: Contemporary Methods, New Insights, ed. Gabriella Gelardini (Biblical Interpretation 75; Leiden/Boston: Brill, 2005): 107-27; Verhärtet Eure Herzen Nicht: Der Hebräer, Eine Synagogenhomilie Zu Tischa Be-Aw (Biblical Interpretation; Leiden/Boston: Brill, 2007)) to situate this perspective more concretely in a post-70 religious context. (In Gelardini's intriguing if somewhat overdetermined case, that context is the Festival of the Ninth of $\mathrm{Ab}$.)
} 
days, after previously speaking through the prophets. The Son's word reached the author and his readership indirectly, 'through those who had heard him' (2.3).

As we will see, the present-day dynamic of believers' relationship with the high priestly Jesus is in important respects marked by his heavenly absence, which is repeatedly conceptualized in terms of spatial distance.

The language of Jesus' personal presence and action in the world, by contrast, relates overwhelmingly to the past, to 'the days of his flesh' (5.7) when he was tempted in every way as believers are and when he patiently suffered on the cross 'outside the gate' (13.12; cf 12.2). His visible presence, it seems, belongs exclusively to that incarnate past: it was done once and came to an end $(9.26,28)$.

All in all, Hebrews lends remarkably strong support to a view similarly supported by three of the four evangelists: since the end of his incarnate ministry on earth Jesus is now not here but risen and ascended to another place (cf. Mark 16.6 parr; Acts 1.11). This in turn raises for all these writers the question of how to relate to him now.

\section{The Absence of Jesus in His Heavenly Now}

So for Hebrews, where is Jesus now? As 'great High Priest' he 'passed through' the halls and curtains of the heavenly sanctuary into the Holy of Holies and his locus now is to be seated at the right hand of the majestic heavenly throne itself $(4.14 ; 8.1-2 ; 9.24 ; 10.12$; cf. 12.23-24). ${ }^{9}$ As the unique and all-surpassing High Priest, Jesus is not merely holy but both 'distanced from sinners' and 'exalted above the heavens' (7.26). The heavenly sanctuary is a place he has entered not just once upon a time, as perhaps at the time of his sacrifice on the cross; nor does he do so annually on an ongoing basis, as the Levitical High Priests do. Instead, Jesus entered 'once and for all' and remains there for ever (9.12; cf. 6.20; 7.24) - a core conviction for Hebrews. ${ }^{10}$ It is precisely as such that he is now perpetually at the right

\footnotetext{
${ }^{9}$ I cannot here pursue the debate about whether Jesus' high priestly status predates his incarnation or dates from his birth, death or exaltation. For a survey of the options see e.g. Christopher A. Richardson, Pioneer and Perfecter of Faith: Jesus' Faith as the Climax of Israel's History in the Epistle to the Hebrews (Wissenschaftliche Untersuchungen Zum Neuen Testament; Tübingen: Mohr Siebeck, 2012), 28-33.

${ }^{10}$ For a recent analysis of the dialectic of uniqueness and repetition in Hebrews, see most fully Nicholas J. Moore, 'Jesus as 'the One Who Entered His Rest': The Christological Reading of Hebrews 4.10', Journal for the Study of the New Testament 36 (2014): 383-400.
} 
hand of God as 'pioneer and perfecter of faith', the 'apostle and high priest of our confession', and the 'forerunner on our behalf' (12.2; 3.1; 6.20; cf. 2.10).

Hebrews goes out of its way to separate what Jesus is and does now from the earthly past in which he was incarnate. Indeed, the thought of any ongoing ministry of Jesus in the world is to this writer explicitly hypothetical and counterfactual. If Jesus' sanctuary were on earth he would not - and as a non-Levite he could not - be a priest at all (8.4; cf. 7.14). And so his 'much more excellent ministry', although relevant to believers, is necessarily and emphatically heavenly rather than earthly and Levitical (8.6). The earthly sanctuary is merely the 'antitype' of the true and heavenly one in which he now appears before God on our behalf, having accomplished his earthly sin-bearing sacrifice of Yom Kippur 'once and for all' $(9.24-26)$.

\section{The Jesus of Hebrews: Absent but Accessible?}

Nevertheless, to affirm only the distance separating the believer's world from Jesus would fail to do justice to the author's message. Although in an important sense now remote from the world in which he became incarnate, it turns out that Jesus is in several other key respects far from disconnected or inaccessible to the lives of believers.

\section{The Sustaining Jesus}

One immediate and timeless exception to any idea of complete absence is the Son's ongoing role as sustainer of the cosmos. Not only did God create the world through him (1.2; cf. 2.10; 3.3 - a notion familiar from other New Testament writers ${ }^{11}$ ), but Hebrews explicitly affirms the corollary that it is the Son who directly sustains, guides and preserves the world by his powerful word (1.3; cf. Col 1.17). Hebrews does not greatly develop this thought in the remainder of the text, and it is perhaps debatable to what extent this general affirmation should be included in a discussion specifically of the presence of Jesus. Nevertheless, its affirmation of the Son's agency in the continuity of creation does provide an important backdrop for the more specific evidence to which I now turn.

\section{The Pastoral Jesus}

The first point to note is that the author repeatedly relies on the very pastness of what Jesus suffered in the 'days of his flesh' to ground his conviction that Jesus somehow exercises

\footnotetext{
${ }^{11}$ See e.g. John 1.3, 10; 1 Cor 8.5; Col 1.16.
} 
Page 8 of $\mathbf{2 1}$

here and now a particularly powerful pastoral empathy with believers in their own weaknesses - an expression of what has been called the 'beneficent' or 'philanthropic' Christology of Hebrews. ${ }^{12}$ We hear repeatedly that Jesus' own redemptive sufferings under trial enable him to 'take hold of' and 'help' those undergoing trials now (e.g. 2.16, 18; 4.15; 12.2; cf. 6.7-9, in each case supported by verbs in the present tense). Christ's faithfulness as God's Son and his public confession of God's name makes possible the pride, confidence and hope which believers enjoy in knowing themselves to be his family, his brothers and sisters $(2.9,11-13$, invoking Ps 22.22 and Isa 8.17-18), and his partners $(3.6,14)$ - a point to which we will return in a moment.

Jesus who 'passed through the heavens' and entered into the heavenly sanctuary is himself the 'anchor' of Christian hope in his presence (6.19-20). It is precisely as the crucified and resurrected one that he is identified in the closing benediction as the 'great Shepherd of the sheep' (13.20). This is in other words no merely notional or impersonal sympathy but an active 'compassion' that exceeds a merely human High Priest's fellow feeling. It is pertinent and presumably in some sense present to believers in their suffering and need (4.16)..$^{13}$

Interestingly, then, for Hebrews Jesus' very absence functions to undergird his decidedly present gift of help and confidence to believers. Although the explicit language of presence is not used, Jesus' high-priestly office appears to effect a remarkably attentive pastoral provision for believers.

\section{The Speaking Jesus}

That priestly ministry on behalf of believers is exercised not just in sympathy but also by the spoken word. The divine word is indeed living and present, sharply piercing to the spirit and judging the heart (4.12). God speaks to the Son $(1.5-13 ; 5.5-6 ; 7.17,21)$ and the Son

\footnotetext{
12 Thus Kevin B. McCruden, Solidarity Perfected: Beneficent Christology in the Epistle to the Hebrews (Bznw; Berlin/New York: de Gruyter, 2008), 45-49 and passim.

${ }^{13}$ Cf. Harold W. Attridge, The Epistle to the Hebrews: A Commentary (Hermeneia; Philadelphia: Fortress Press, 1989), 143; McCruden, Solidarity Perfected: Beneficent Christology in the Epistle to the Hebrews , 104, 109-10. While the resurrection's significance for Hebrews was often questioned in the past, more recent scholarship has rightly corrected this view; see esp. David M. Moffitt, Atonement and the Logic of Resurrection in the Epistle to the Hebrews (Supplements to Novum Testamentum; Leiden/Boston: Brill, 2011); 'The Role of Jesus' Resurrection in the Epistle to the Hebrews, Once Again: A Brief Response to Jean-René Moret', New Testament Studies 62 (2016): 308-14.
} 
Page $\mathbf{9}$ of $\mathbf{2 1}$

speaks to God $(2.12-13 ; 10.5-7)$, each confirming to the other the Son's identity and selfgiving priestly work of salvation. ${ }^{14}$ Importantly, God has also spoken 'to us' in and by the Son $(1.2 ; 2.2-3)$. This lies in the past, but that speech of God in Jesus emphatically also implicates an address 'today' precisely in the light of 'such a great salvation' (2.3). This emphatic currency and urgency ${ }^{15}$ of God's saving word in the Son grounds the letter's appeal to the readers especially in the early chapters (3.7-4.11). Like God, the Holy Spirit in particular also addresses readers in the present, showing the prophetic word of God to be 'living and powerful' (4.12) by making it contemporaneous as a direct and personal address to today's wandering people of God on their way to the promised land and city (3.7-11). ${ }^{16}$

Still more concretely, Jesus himself also now 'speaks' in the present, but does so 'from heaven' - above all through the merit of his sacrificial blood (7.25; 12.24-25). After 1.12 it is at times not straightforward to distinguish between what Jesus says and what God says, but there is no question that they both speak, and that their utterance extends to a present as well as a past dimension.

\section{The Familial Jesus}

Even in the contemporary reality of absence or at least of distance, however, the invocation of the familial language of 'children' and 'brothers' $(2.9,11-13)$ functions as a way of expressing divine intimacy and presence even in the experience of Jesus' absence, not least with reference to the quotation of Isaiah 8.17-18. ${ }^{17}$ Christ is also described as the faithful Son in charge of his Father's family (lit. 'house'): although he is not now present, 'we are his family if indeed we hold fast to the confidence and pride of hope' - an affirmation relevant to all those who 'today' hear his voice (3.6-718) and who by the same token have become his partners (3.13-14).

\footnotetext{
14 See discussion in Tomasz Lewicki, "Weist Nicht Ab Den Sprechenden!": Wort Gottes Und Paraklese Im Hebräerbrief (Paderborner Theologische Studien; Paderborn: Schöningh, 2004), 28-47.

${ }^{15}$ Cf. "Weist Nicht Ab Den Sprechenden!": Wort Gottes Und Paraklese Im Hebräerbrief , 91-94.

16 Luke Timothy Johnson, Hebrews: A Commentary (New Testament Library; Louisville: Westminster John Knox Press, 2006), 113.

17 This is a point rightly stressed by Angela Rascher, Schriftauslegung Und Christologie Im Hebräerbrief (Bznw; Berlin/New York: Walter de Gruyter, 2007), 93-95.

${ }^{18}$ Note that NRSV and other translations consistently render what is said of Christ here in the past tense, for which the Greek text provides remarkably limited support.
} 
An evocative subsidiary theme of relevance to the familial Jesus is that of inheritance. Not only is Jesus the heir of all things including his superior name $(1.2,4)$, but he is the Son who leads other sons and daughters, who presides over the assembly of the firstborn, the assembly is the assembly of the firstborn, etc. In the Old Testament Noah and Abraham were already heirs of a divine inheritance the Old Testament $(11.7,8)$, just as Esau squandered his (12.8); but Jesus has become for those who believe the mediator of a new covenant, providing an eternal inheritance of the promise of salvation $(1.14 ; 6.12 ; 9.15) .{ }^{19}$ Although less immediately concerned with the motif of presence or absence, believers' familial adoption and joint inheritance with Jesus does suggest a way in which the problem of his absence may be mediated.

\section{The Accessible Jesus}

Just as the author urges believers to enter the eschatological rest of the promised land and city prepared for them by their Joshua-like leader Jesus (4.1-11), ${ }^{20}$ so also he strongly encourages them to 'approach with confidence the throne of grace' (4.16) - and him who has made that access possible. Such an approach is not just optional but essential in order to benefit from Christ's eternal priesthood: his saving action and constant intercession is explicitly for 'those who approach God through him' (7.25). Indeed, it would appear that Jesus' entry into the heavenly Holy of Holies is worth very little to those who do not follow him there: Jesus' entrance into the heavenly sanctuary has become not merely the fruit and reward of his own distinct merit and achievement, but the way for believers to follow. Jesus' priesthood introduces the 'better hope' through which Christians draw near to God (7.19). Believers are strongly urged to seize the 'firm anchor' of that hope, which even now

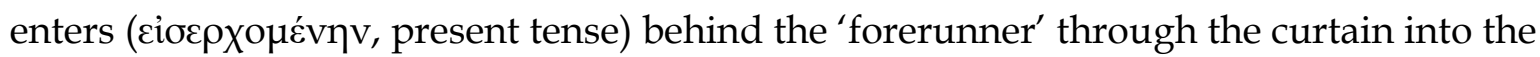
heavenly sanctuary (6.18-20). This is far from an empty theoretical or impossible demand. Instead, it concerns what through Jesus' death has become the real 'new and living' pathway by which believers may and should enter with confidence (10.19-20).

\footnotetext{
19 See on this subject the work of Dana M. Harris, 'The Eternal Inheritance in Hebrews: The Appropriation of the Old Testament Inheritance Motif by the Author of Hebrews' (PhD dissertation, Trinity Evangelical Divinity School, Deerfield, 2009), to whom I am grateful for drawing her research to my attention. ${ }^{20}$ Cf. Richard J. Ounsworth, Joshua Typology in the New Testament (Wissenschaftliche Untersuchungen Zum Neuen Testament; Tübingen: Mohr Siebeck, 2012) passim.
} 
The language of 'entry' and 'approach' draws attention to the significance of location and movement for the dynamic of presence in Hebrews. Jesus' presence to believers may be a function of the extent to which they draw near to him.

Believers in Jesus both already possess a promise to 'enter' the eschatological rest and yet must be 'zealous' to enter it $(4.1,11)$. The relationship between this indicative and its cognate imperative gives rise to a number of well-known interpretative difficulties about believers' participation in their own salvation in Hebrews and other parts of the New Testament, to which we cannot do justice here. ${ }^{21}$ Yet the location of believers as 'coming' or 'drawing near' appears to be in some sense functionally determinative for the presence or absence of Jesus, which may have as much or more to do with where believers are vis-à-vis his position in the inner sanctuary.

This may also be what is envisaged by the striking imagery in chapter 6 of an 'anchor' of hope that needs to be 'seized' even as it is already entering the 'inner shrine' where Jesus acts as High Priest (6.19-20). While exhortation appears to prevail here, the assurance in 13.10 that 'we have an altar' appears to confirm the sort of presence that grants confidence in the work of Jesus as both high priest and victim to surpass that of the earthly cult.

\section{The Visible Jesus}

Another striking and unexpected corollary of Jesus' absence is the assertion that believers nevertheless now 'see' him in his heavenly exaltation, crowned with the martyr's glory. Since this is affirmed as a kind of inclusion both near the beginning and near the end of Hebrews, it seems pretty evidently intended for emphasis. Having stressed the Son's superiority to the angels, the writer pointedly notes that while we cannot yet 'observe' (ó $\tilde{\rho} \mu \varepsilon v)$ the world subjected to the Son's eschatological rule, we do in fact even now 'see' ( $\beta \lambda \dot{\varepsilon} п о \mu \varepsilon v)$ the same Jesus who suffered now crowned with the martyr's honour in glory

\footnotetext{
${ }^{21}$ Fulcrum passages in Hebrews include 6.4-8 and 10.26-27. Such texts often affected later debates about the possibility of forgiveness for post-baptismal sin, the irreversibility of election (or the 'perseverance of the saints'), etc. See e.g. Jason A. Whitlark, Enabling Fidelity to God: Perseverance in Hebrews in Light of the Reciprocity Systems of the Ancient Mediterranean World (Carlisle Milton Keynes: Paternoster, 2008); P. H. R. van Houwelingen, 'The Epistle to the Hebrews: Faith Means Perseverance', Journal of Early Christian History 3 (2013): 98-115; David B. Armistead, 'The 'Believer' Who Falls Away: Heb 6:4-6 and the Perseverance of the Saints', Stulos 4 (1996): 139-46; also David W. T. Brattston, 'The Forgiveness of Post-Baptismal Sin in Ancient Christianity', Churchman 105 (1991): 332-49.
} 
(2.8-9). ${ }^{22}$ Even where not perhaps explicitly seen, he can be 'considered carefully' by those

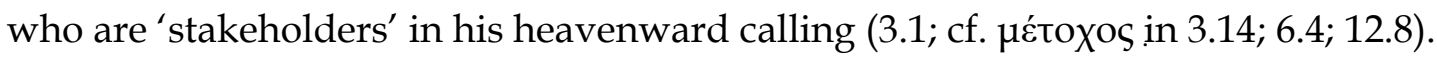

This surprisingly visual note of proleptic pilgrimage to the promised land finds its counterpart in the realized ascent to the true Zion in chapter 12. All the saints of the old

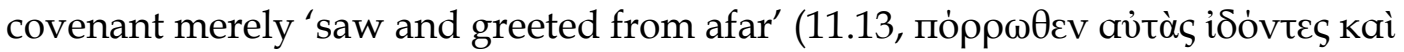
גonवбá $\mu \varepsilon v o \imath)$ what believers in Jesus have been granted to attain: they are now able to 'look at' (ג்

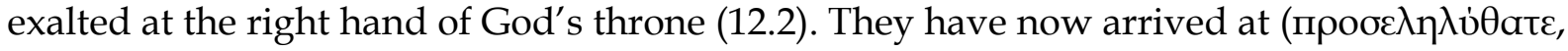
12.22) the heavenly Jerusalem for which the patriarchs looked (11.16), and have in fact come to its Lord, 'Jesus the mediator of the new covenant' (12.24).

To say that Jesus is both visible and accessible to Christian faith evidently constitutes an important qualification of the seemingly dominant presupposition of his distance and absence. He is not here - but believers are at least in some sense enabled and indeed encouraged to 'see' him and to 'come to' him. His visibility in that sense is an important expression of his accessibility. ${ }^{23}$

This perhaps unexpected language of sight is clearly an important rhetorical feature, as recent study has demonstrated with reference to the classical appeal to visual description (ekphrasis). ${ }^{24}$ With the obvious exception of the Book of Revelation, few other New Testament writings appeal quite so emphatically to the reader's visual imagination. ${ }^{25}$

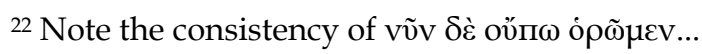

${ }^{23}$ On an equally intriguing note not directly concerned with Jesus, Hebrews elsewhere stresses the accessibility of God's heavenly gift of word and Spirit to the senses in terms of light and taste (6.4-5), evidently supporting the notion that such presence can be experienced.

${ }^{24}$ See Scott D. Mackie, 'Visually Oriented Rhetoric and Visionary Experience in Hebrews 12: 1-4', Catholic Biblical Quarterly 79 (2017): 476-97 on visuality in Hebrews 12.1-4 as conditioned by ekphrasis. Key points of reference in the secondary literature include Jaś Elsner, Art and the Roman Viewer: The Transformation of Art from the Pagan World to Christianity (Cambridge: Cambridge University Press, 1995); Roman Eyes: Visuality and Subjectivity in Art and Text (Princeton/Oxford: Princeton University Press, 2007); Ruth Webb, Ekphrasis, Imagination and Persuasion in Ancient Rhetorical Theory and Practice (Farnham: Ashgate, 2009); 'Site and Inside: Theorising Vision, Emotion and Imagination in Ancient Rhetoric' in Sight and the Ancient Senses, ed. Michael Squire (The Senses in Antiquity; Abingdon: Routledge, 2016): 205-19; also Michael Squire, ed., Sight and the Ancient Senses (The Senses in Antiquity; Abingdon: Routledge, 2016); Graham Zanker, Modes of Viewing in Hellenistic Poetry and Art (Madison: University of Wisconsin Press, 2004); Helen Morales, Vision and Narrative in Achilles Tatius' Leucippe and Clitophon (Cambridge: Cambridge University Press, 2004).

${ }^{25}$ On Revelation see e.g. Robyn J. Whitaker, Ekphrasis, Vision, and Persuasion in the Book of Revelation (Wissenschaftliche Untersuchungen Zum Neuen Testament; Tübingen: Mohr Siebeck, 2015), Gregory M. 
For the writer to the Hebrews, moreover, this visual appeal is not easily reducible to a convenient rhetorical device or a figure of speech. On the one hand, the letter's controversially ambiguous definition of faith as the 'reality' of things hoped for and the testing or corroboration of 'things not seen' (11.1) might indeed seem to favour a conception of faith as rational rather than visual, not to say 'blind'. And yet there is no mistaking the fact that the narrative goal and hope shared by the heroes of faith in chapter 11 is precisely to see and look to the reward of the promised country and city they seek to reach. Already in the case of Noah, the chapter's opening definition seems to be subtly relativized in relation

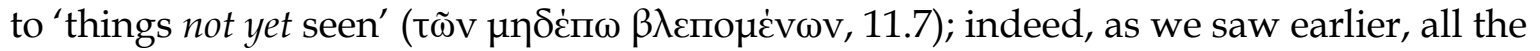
Old Testament saints are said to have 'seen and greeted' the fulfilment of the promises from afar (11.13).

Although visual and perhaps even visionary, this dimension is also not conventionally apocalyptic: the heavens do not open, the author discloses no esoteric visions of cosmological or eschatological secrets, and there are few if any signs of a desire to correlate heavenly revelations with earthly political or natural events. Commentators

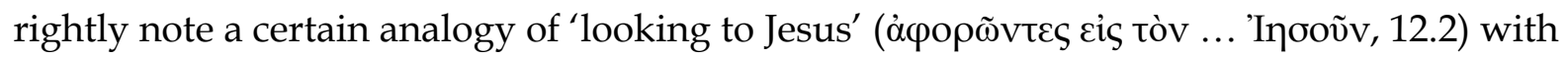
the roughly contemporary Jewish author of 4 Maccabees, who writes that the martyrs in

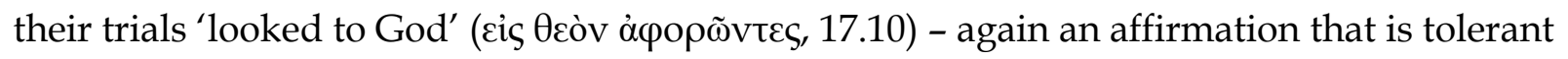
of visionary motifs, without however requiring an elaborate experiential or mystical toolkit. Within Hebrews, similarly, Moses features as a hero of faith in that he discarded Egypt's

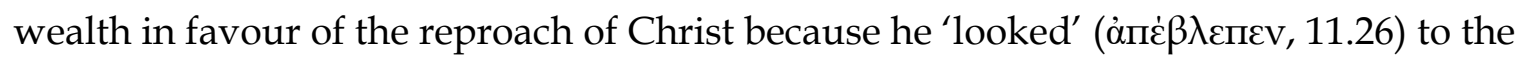
reward that was to come.

Barnhill, 'Seeing Christ through Hearing the Apocalypse: An Exploration of John's Use of Ekphrasis in Revelation 1 and 19', Journal for the Study of the New Testament 39 (2017): 235-57 and Alexander E. Stewart, '"Ekphrasis", Fear, and Motivation in the Apocalypse of John', Bulletin for Biblical Research 27 (2017): 227-40. Related arguments have been made e.g. for Paul (J. M. F. Heath, Paul's Visual Piety: The Metamorphosis of the Beholder (Oxford: Oxford University Press, 2013)), 1 Peter (David G. Horrell et al., 'Visuality, Vivid Description, and the Message of 1 Peter: The Significance of the Roaring Lion (1 Peter 5:8)', Journal of Biblical Literature 132 (2013): 697-716) and also, more obviously, for second-century apocalypses (Meghan R. Henning, 'Eternal Punishment as Paideia : The Ekphrasis of Hell in the Apocalypse of Peter and the Apocalypse of Paul', Biblical Research 58 (2013): 29-48) as well as Papias on the death of Judas (Christopher B. Zeichmann, 'Papias as Rhetorician: Ekphrasis in the Bishop's Account of Judas' Death', New Testament Studies 56 (2010): 427-29). 
Paradoxically, the writer's paraclesis makes clear that 'seeing' Jesus is not yet exhaustively or inalienably available: it is still something that remains eschatologically contingent on continued sanctification, without which 'no one will see the Lord' (12.14). And there is a degree of analogy with the Old Testament saints in the affirmation that Christians too are still 'looking for the city that is to come', since there is no abiding city here (13.14). Evidently, then, there is a future, eschatological dimension to the seeing of Jesus, just as his return is described in 9.26-28 in terminology reminiscent of the resurrection appearances. ${ }^{26}$ We will return briefly to the presence of Jesus in the Parousia below.

Most striking, perhaps, is the accentuated visual and auditory appeal of chapter 12. Although seeking to contrast it with the superior heavenly Mount Zion, the author nevertheless powerfully evokes the tactile Mount Sinai with its 'blazing fire, and darkness, and gloom, and a tempest, and the sound of a trumpet', the unbearable power of the voice of God, and its intensely terrifying sensations of touch, sound and sight. These motifs of Exodus 19 are expressed in ways reminiscent of their reception in a range of Jewish texts from Wisdom and Philo to the rabbis. ${ }^{27}$

Meanwhile the surrounding cloud of the previous chapter's Old Testament saints witnesses the believers' present struggles and arrival at the heavenly Mount Zion as a grand spectacle 'in a stadium-like setting under the gaze of the heroes of faith, Jesus, and God, who are all present as avid and sympathetic spectators.'28

It is true that God remains in chapter 12 both judge and 'consuming fire $(12.23,29$; cf. 10.30; 13.4). That said, however, the account of believers' entrance to Mt Zion paints a scene of serene but equally powerful celestial beauty, in which the corporate worship of heaven culminates in the presence of God and of Jesus. Even if the auditory and visual description

\footnotetext{
26 Thus rightly Wilfried Eisele, Ein Unerschütterliches Reich: Die Mittelplatonische Umformung Des Parusiegedankens Im Hebräerbrief (Beihefte Zur Zeitschrift Für Die Neutestamentliche Wissenschaft 116; Berlin/New York: de Gruyter, 2003), 74-76, 128.

${ }^{27}$ For the Jewish trajectory of reception see e.g. Steven D. Fraade, 'Hearing and Seeing at Sinai: Interpretive Trajectories' in The Significance of Sinai: Traditions About Sinai and Divine Revelation in Judaism and Christianity, ed. George J. Brooke et al. (Leiden/Boston: Brill, 2008): 247-68.

${ }^{28}$ Mackie, 'Visually Oriented Rhetoric and Visionary Experience in Hebrews 12: 1-4' , 497.
} 
of that presence appears less concrete and granular, it is nevertheless in this graphic context that the readers are exhorted to 'behold/look to Jesus' (12.2).

The prominence of a visual apprehension of Jesus in chapter 12 raises the possibility that it might be important elsewhere in Hebrews. ${ }^{29}$ For example, talk of 'passing through the heavens' and 'entering behind the veil' may at least hint at something of the evocative visual dimension in Josephus' description of the High Priest's passage through the Jerusalem Temple's rooms and curtains. ${ }^{30}$ Unlike Josephus, whose account of the decorations on the Pentateuchal Menorah may reflect Second-Temple realities including the depiction on the Arch of Titus as much that it does the Book of Exodus, Hebrews 9 appears not to appeal specifically to any remembered visuality of the Jerusalem Temple in its description of the Tabernacle cult. ${ }^{31}$ It does draw on Pentateuchal as well as later traditions, including the lampstand and showbread table separated by a curtain from the Holy of Holies with its exquisite golden sanctuary furnishings of the Altar, the Ark and its contents including a separate golden urn with manna (9.2-5).

More to the point, however, we find in the Songs of the Sabbath Sacrifice from Qumran and Masada perhaps the most important antecedent to Hebrews' idea of a permanent heavenly sanctuary whose structure and colourful curtains mirror that of its earthly 'copy'. ${ }^{32}$ Its acts of worship are envisaged in such strikingly graphic terms as to encourage the thought that the worshippers 'seek to see what Moses saw.'33 That Judaean writer may additionally be aware of traditions of apocalyptic throne visions like Isaiah 6 and Ezekiel 1, which also influenced the book of Revelation as well as other Jewish and Christian visionary texts. ${ }^{34}$ Given the appeal in chapter 12 to worship in the heavenly city in the

\footnotetext{
${ }^{29} 13.7$ may stress a visual memory of the apostolic mission in urging the readers to 'remember' their

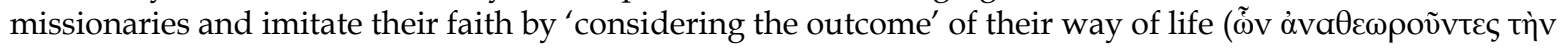

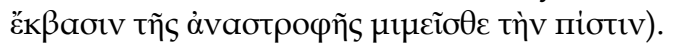

30 The progression through the outer to the inner parts of the sanctuary, with its successive curtains decorated with symbols of the heavenly world, seems clear at 9.3 (cf. 6.19; 10.20). It is affectionately described by Josephus, Jewish War 5.207-19. Cf. also m. Yoma 5.1-2.

31 It is, however, unclear to what extent the 'seeing' of Jesus relates to a visuality informed by memory.

32 4Q403 1.i.1-17, 41-44; cf. 4Q405 15.ii-16.1-7 for the beauty of the multi-coloured curtain (on which cf. Jared C. Calaway, The Sabbath and the Sanctuary: Access to God in the Letter to the Hebrews and Its Priestly Context (Wissenschaftliche Untersuchungen Zum Neuen Testament; Tübingen: Mohr Siebeck, 2013), 131-35. 33 The Sabbath and the Sanctuary: Access to God in the Letter to the Hebrews and Its Priestly Context, 131 (127-31). 34 Cf. Dan 7.9; 1 Enoch 14, 71; Apocalypse of Abraham 18; Testament of Levi 2.6-3.9; 5.1, 6 etc., along with the extensive later Jewish mystical Hekhalot ('heavenly palaces') literature.
} 
Page $\mathbf{1 6}$ of $\mathbf{2 1}$

company of 'tens of thousands of angels' and the festal 'congregation of the firstborn enrolled in heaven', the relevance of some such visual connections seems at least plausible. ${ }^{35}$ They are in my view rather more likely, for example, than occasional attempts to extract from Hebrews a specifically Eucharistic interpretation of the visible and accessible Jesus. 36

The Vulnerable Jesus

One minor but also unexpected theme is the apparent assumption that apostasy somehow re-enacts the public shaming of Christ in the crucifixion (6.6). ${ }^{37}$ Whether this is regarded as an action identical to the mob baying for Jesus' blood or merely as its moral equivalent is perhaps unclear. Nothing in the text requires that a re-crucifixion of Jesus is anything other than an impossible possibility - perhaps in keeping with the fact, widely noted among commentators, that the author does not here address anything other than a hypothetical case of apostasy. Jesus is evidently in some important sense present to the rejection of apostasy. 'Apostates, by rejecting Christ, ridicule him and put him on display.'38

That said, it seems that his wilful rejection by those who are now his 'brothers and sisters' has the potential even now to cause Jesus injury. He is, in other words, present not only to the movement of faith drawing near to God but also to the wilful opposite of that

${ }^{35}$ Cf. On this subject Jody A. Barnard, The Mysticism of Hebrews: Exploring the Role of Jewish Apocalyptic Mysticism in the Epistle to the Hebrews, Wissenschaftliche Untersuchungen zum Neuen Testament 2:331 (Tübingen: Mohr Siebeck, 2012), 171-216, although his equation of Hebrews 'throne' language specifically with merkavah mysticism $(116,184-87$ etc.) may be overly hasty.

${ }^{36}$ So especially James Swetnam, 'In Search of the Hebrews 9, 2 Grail', Melita Theologica 60 (2009): 15-24; 'Christology and the Eucharist in the Epistle to the Hebrews', Biblica 70 (1989): 74-95; cf. previously Paul Andriessen, 'L'eucharistie Dans L'épître Aux Hébreux', Nouvelle Revue Théologique 94 (1972): 269-77 and the earliest sustained treatment by John Edward Field, The Apostolic Liturgy and the Epistle to the Hebrews: Being a Commentary on the Epistle in Its Relation to the Holy Eucharist. With Appendices on the Liturgy of the Primitive Church (London: Rivingtons, 1882) (neither of them cited by Swetnam). Most commentators have tended to side with the fierce critique of Ronald Williamson, 'Eucharist and the Epistle to the Hebrews', New Testament Studies 21 (1975): 300-12. Recent sympathetic treatments include Arthur A. Just, Jr., 'Entering Holiness: Christology and Eucharist in Hebrews', Concordia Theological Quarterly 69 (2005): 75-95; Roch A. Kereszty, 'The Eucharist in the Letter to the Hebrews', Communio 26 (1999): 154-67. The speculative dissertation of Roberto Abeynaike, The Eucharist in Relation to the Priesthood of Christ in the Letter to the Hebrews (Rome: Pontificium Institutum Biblicum, 2008) goes even further to argue that Hebrews is specifically a commentary on the words and actions of Jesus at the Last Supper. But that the words of institution and the letter to the Hebrews alike offer a sacrificial interpretation of the death of Christ does not make the latter a deliberate commentary on the former, even if on broader biblical and theological grounds they are each tolerant of being read in light of the other (as e.g. Clement of Alexandria, Strom. 4.25 does in relation to 7.2 or Bede, Homilies on the Gospels 1.15 on 7.17 )

${ }^{37}$ Thus cf. Paul Ellingworth, The Epistle to the Hebrews: A Commentary on the Greek Text (Nigtc; Grand Rapids/Carlisle: Eerdmans/Paternoster, 1993), 324-25

${ }^{38}$ Attridge, The Epistle to the Hebrews: A Commentary , 171. 
movement. At least in this relatively tangential comment, therefore, it seems that Jesus is understood by this author to be present and personally affected in the commitment both of faith and of unbelief.

A hint at an element of correlated suffering in rejection may surface in another passage near the end of the letter (13.12-14). Jesus suffered rejection outside the 'camp' of the earthly Jerusalem, ${ }^{39}$ which is where Hebrews encourages its Jewish Christian audience to join him without fear or shame. To some extent paradoxically, then, the wandering people of God can be invited to be present to him at the place of his disgrace and suffering, where he sanctified them outside the walls of the earthly Jerusalem. It seems that the mere pastness of his death does not eliminate the call to go outside the 'camp' to be in some meaningful sense in his presence there.

\section{The Returning Jesus}

For all the emphasis on the present summons of believers to follow Jesus both outside the gate and beyond the curtain in the heavenly Mount Zion, there remains an inescapable sense of spatial as well as temporal separation. The 'days of his flesh' lie firmly in the past, and Hebrews exhorts believers to expect the 'approaching' day of his coming and their reward (10.25, 35-37). Jesus remains 'the one who is coming' (10.37, citing Hab 2.3 LXX), ${ }^{40}$ and he himself is still awaiting the surrender of his enemies (10.13). Thus also believers await both Jesus and 'the city that is to come' (13.14). ${ }^{41}$ The nature of Jesus' personal presence in his two eschatological appearances - the incarnation and the Parousia - is notably different but nevertheless analogous: just as in his first coming he was 'made

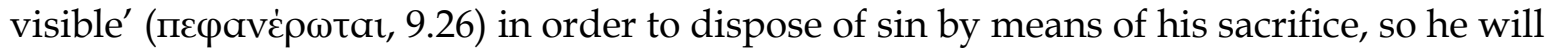
'appear for the second time to deliver salvation for those who are eagerly waiting for

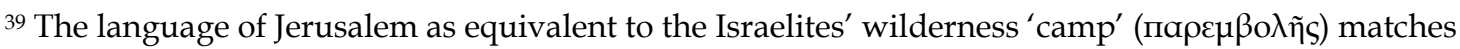
Hebrews' cultic imagery relating explicitly to the Pentateuchal Tabernacle rather than the Second Temple. The hermeneutical principle that the laws about the camp now apply to Jerusalem is similarly encountered in several of the Dead Sea Scrolls, perhaps most explicitly in 4QMMT (e.g. 4Q394 frgs 3-7:ii.16-17; 4Q397 3:3). Rev 20.9 may reflect a similar conception.

40 The importance of this text for Hebrews is extensively developed by Radu Gheorghita, The Role of the Septuagint in Hebrews: An Investigation of Its Influence with Special Consideration to the Use of Hab 2:3-4 in Heb 10:37-38 (Wissenschaftliche Untersuchungen Zum Neuen Testament; Tübingen: Mohr Siebeck, 2003). 41 See e.g. Scott D. Mackie, Eschatology and Exhortation in the Epistle to the Hebrews (Wissenschaftliche Untersuchungen Zum Neuen Testament; Tübingen: Mohr Siebeck, 2007), 124-51 and passim for a fuller discussion of the relationship of ethics and eschatology in Hebrews.
} 
him.' ${ }^{42}$ Moses in this respect remains an exemplar of faith even for Christians, as one who treasured 'the reproach of Christ' above all Egyptian riches because he had his eyes on the reward (11.26).

In attempting to resolve the peculiar shape of Hebrews' eschatology, some interpreters rightly note its combination of an apparent cosmological dualism with a salvation story of 'two ages' that maps closely onto the succession of the two covenants, with aspects of the old covenant continuing until the earthly creation fully gives way to the heavenly at the Day of the Lord. ${ }^{43}$ But quite how radical and discontinuous is the shape of that cosmological and salvation historical dualism?

Here the rhetorically pivotal ${ }^{44}$ passage $12.18-29$ carries important weight. Even earlier in the discourse Hebrews does envisage the created order to be shaken to its foundations in connection with the imminent return of Jesus as judge $(9.28 ; 10.13,37)$. Now, however, this tremor is set in parallel to the conviction that God is a 'consuming fire', leaving only an 'unshaken kingdom' to remain (12.26-29). More than a few commentators, however, strain this 'narrative' of Hebrews in an unnecessarily Platonizing direction when they read the difficult verse 12.27 as entailing the annihilation without remainder of all creation. ${ }^{45}$

Taken to its logical conclusion, this widely held and ancient interpretation requires that the presence of Jesus in the Parousia undergoes in Hebrews a thoroughgoing transformation in middle Platonic terms. ${ }^{46}$ Here the remaining time before the shaking of heaven and earth on the Day of the Lord relates purely to the personal fate of Christians:

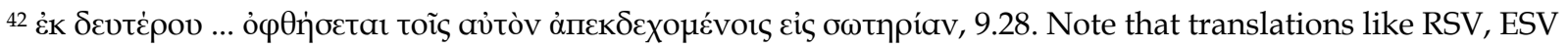
obscure the meaning by rendering 'then to wait'.

43 So e.g. Kenneth Schenck, Cosmology and Eschatology in Hebrews: The Settings of the Sacrifice (Snts Monograph Series; Cambridge/New York: Cambridge University Press, 2007), 183-90 and passim

${ }^{44}$ Recent authors like Lukas Stolz, Der Höhepunkt Des Hebräerbriefs: Hebräer 12,18-29 Und Seine Bedeutung Für Die Struktur Und Die Theologie Des Hebräerbriefs (Wissenschaftliche Untersuchungen Zum Neuen Testament; Tübingen: Mohr Siebeck, 2018) have argued for Heb 12.18-29 as the rhetorical climax of the letter. Cf. similarly Christopher T. Holmes, The Function of Sublime Rhetoric in Hebrews: A Study in Hebrews 12:18-29

(Wissenschaftliche Untersuchungen Zum Neuen Testament; Tübingen: Mohr Siebeck, 2018).

45 Thus e.g. Attridge, The Epistle to the Hebrews: A Commentary , 380-81 and those he cites; Eisele, Ein Unerschütterliches Reich: Die Mittelplatonische Umformung Des Parusiegedankens Im Hebräerbrief as discussed below; cf. also Schenck, Cosmology and Eschatology in Hebrews: The Settings of the Sacrifice, 183, 189.

${ }^{46}$ Thus explicitly Eisele, Ein Unerschütterliches Reich: Die Mittelplatonische Umformung Des Parusiegedankens Im Hebräerbrief: "tiefgreifende Umformung", 426 and passim.
} 
that second coming of Jesus is then no longer to his people at the consummation of history but rather to the individual believer in heaven immediately upon his or her death. ${ }^{47}$

While such a tidy resolution undoubtedly flatters traditional dualistic or supersessionist readings of Hebrews, several exegetical observations should nevertheless give us pause. It is the created world into which faith's pioneer and perfecter entered to

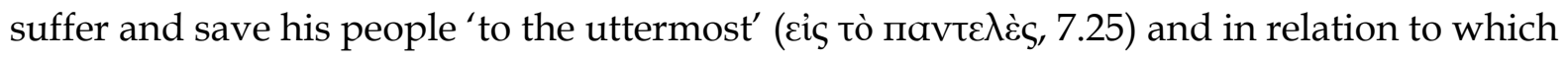
he was 'brought up from the dead' $\left(13.20^{48}\right)$. Indeed, hope in the resurrection of the dead remains for Hebrews foundational to Christian faith (6.1-2; cf. 11.19, 35). But evidently it is the same world to which, as 'the coming one' (10.37) he will soon return 'a second time' $(9.28) \cdot{ }^{49}$

Other scholars have rightly questioned the detachment of 12.26-29 from its Jewish interpretative moorings and its connection with the contrasting interpretation of Sinai in 12.18-21: what God 'shakes' is all of heaven and earth, in keeping with God's voice shaking the earth 'then', i.e. at Sinai. ${ }^{50}$ What is 'removed' is more specifically 'the things that can be shaken': evidently the writer envisages a kind of rattle test to distinguish between shakeable and unshakeable things. It seems reasonable to conclude that what is removed at the eschaton is evidently not the entire created universe, but rather those things that are rattled as Mount Sinai was - or the Sinaitic means of access to God. ${ }^{51}$

Believers in Jesus are of course created rather than uncreated, yet notably they possess 'an unshakeable kingdom' even now (12.28). In other words, 'unshaken things' belonging to the redeemed world of the heavenly Jerusalem evidently exist already in the present, and these will be preserved and will 'remain' (12.27) for life after the coming of

\footnotetext{
${ }^{47}$ Ein Unerschütterliches Reich: Die Mittelplatonische Umformung Des Parusiegedankens Im Hebräerbrief , 428. 48 See e.g. Matthew C. Easter, Faith and the Faithfulness of Jesus in Hebrews (Snts Monograph Series; Cambridge/New York: Cambridge University Press, 2014), 118-19 in defence of the preferred reading of 13.20 in relation to include resurrection rather than merely exaltation (pace Attridge, The Epistle to the Hebrews: A Commentary, 406 and some others).

${ }^{49}$ Eisele, Ein Unerschütterliches Reich: Die Mittelplatonische Umformung Des Parusiegedankens Im Hebräerbrief , 129 rightly notes that the latter passage reveals little about the specific shape of the Parousia. ${ }^{50}$ See e.g. Jon C. Laansma, 'Hidden Stories in Hebrews: Cosmology and Theology' in Cloud of Witnesses: The Theology of Hebrews in Its Ancient Contexts, ed. Richard J. Bauckham et al. (Lnts; London etc.: T\&T Clark, 2008): 9-18; Philip A. F. Church, Hebrews and the Temple: Attitudes to the Temple in Second Temple Judaism and in Hebrews (Supplements to Novum Testamentum; Leiden/Boston: Brill, 2017), 355-58 and passim. ${ }^{51}$ Thus persuasively Hebrews and the Temple: Attitudes to the Temple in Second Temple Judaism and in Hebrews , 358.
} 
Jesus. In other words, the writer discriminates not crudely or Platonically between the material and the spiritual, or even between the created and the uncreated, but between that which is made ready to share in the holiness of God and that which is not $(12.10$, cis tò

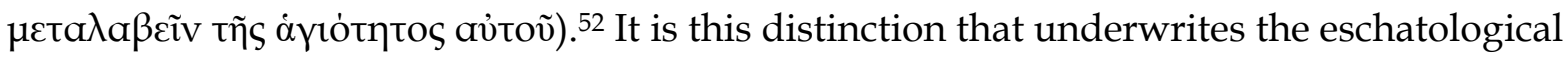
continuity of the presence of Jesus in the unshakeable kingdom.

\section{Conclusion}

So what does this exceptional document contribute to our question of the presence and absence of Jesus? Hebrews' take on our question is undeniably difficult and complex. All the New Testament writers develop a dialectic of presence and absence in their conception of where Jesus is now. Within that dialectic, more than most others, the author to the Hebrews majors on the absence of Jesus from the world of Christian life and discipleship. And yet the author's message is clearly intended as a 'word of encouragement' (13.22), a message to bring hope: evidently the situation of the recipients, quite possibly in light of the devastation of AD 70, is served more urgently by a strikingly lively emphasis on the ongoing atoning high priesthood of Christ before the throne of God in the absence of the earthly cult, rather than by an emphasis on his immediate presence. Where the earthly sanctuary once granted access to God through a fallible High Priest, entry and access are evidently secured more powerfully by Christ's continuing priesthood in heaven than by his presence on earth.

We found that the presence of Jesus is most clearly articulated in relation to his incarnation in the past - a period bounded unambiguously between his birth and his exaltation to the heavenly sanctuary. Unlike for some other New Testament writers, here there is no obvious attempt to sublimate or compensate for the absence of Jesus by sacramental or pneumatological means: the writer does not, for example, appeal to the empowering presence of the Spirit as an authorized Paraclete representing Jesus in his absence, although the Spirit's gifts and speech do make living and active the prophetic word of the Old Testament for the present day. ${ }^{53}$ Nor is Jesus living in and through believers, as in Paul - let alone continually in their midst, as in Matthew. In this as in other

52 Similarly Johnson, Hebrews: A Commentary , 351.

${ }^{53} \mathrm{Heb} 2.4 ; 3.7 ; 8.4 ; 9.8 ; 10.15$. 
respects, Paul is perhaps the New Testament author whose profile most clearly exercised a balancing influence on the reception of Hebrews - facilitating its interpretation in keeping with a dialectic of the absent and present Jesus while being subject in turn to its cultic and sacrificial understanding of his death. There are hints at a genuine communion and 'vision' of Jesus, but no actual visionary experiences are described or narrated.

That said, we have seen numerous indications that the pastness of Jesus' presence to the believers' experienced world of time and space does not invalidate the effective force of who he is and what he did and does. He now ministers in the heavenly sanctuary on believers' behalf, but what he achieved in his incarnation is itself a powerful and abiding ingredient in that ongoing priestly work, and in the expectation of his coming. He sustains the life of his people with concrete empathy: they are his family and fellow heirs, and he is their shepherd; he speaks and remains accessible and indeed in a significant sense visible to believers who seek him, just as he is vulnerable to those who reject and thereby re-crucify him. And his involvement with believers is importantly sustained not only by his past incarnation and powerful heavenly advocacy, but also but his impending return.

Where is Jesus now? Even for the author of Hebrews, the sense of the physical remoteness of Jesus is compatible with his accessibility and closeness - and thus in some sense his presence. Even his absence is such as to sustain his vital connection with believers as 'the same yesterday and today and for ever' (13.8). 